\title{
ON THE EMPIRE'S RUMBLE: TOWARD NEW POLITICAL, SOCIO-ECONOMICAL AND INTERNATIONAL ORDER IN CENTRAL AND EASTERN EUROPE 26-27 th OCTOBER, 2011 UNIVERSITY OF LODZ TRAINING AND CONFERENCE CENTRE
}

\author{
by Michat Stowikowski
}

On 26-27th October 2011 at the University of Lodz Training and Conference Centre there took place an international conference "On the Empire Rumble: Toward New Political, Socio-Economical and International Order in Central and Eastern Europe", organized by the Chair of Political Science, Institute of Political Science Faculty of International Studies and Political Science's.

This was the $8^{\text {th }}$ edition of regularly organized conferences and scientific seminars by the Chair of Political Systems. So far the Chair of Political Science has published 9 textbooks, from 2005 they have been published by Adam Marszałek Publishing House within the Polish publishing series under the aegis of the Polish Political Science Association. The initiative to organize conferences and publish books dedicated to transformational processes in Central and Eastern Europe and integration of the European continent after the end of the Cold War were inspired by prof. Alicja Stępień-Kuczyńska, who is head of the Chair of Political Studies and the Institute of Political Science Executive Director.

The Conference was prearranged under the auspices of the University of Lodz Rector, Marshal of Lodz Voivodship, Executive Committee President of Polish Association of Political Science, Commission for 
studies on European Integration at the Polish Academy of Science in Lodz.

Over 100 scientists and doctoral students from Poland and abroad participated in the conference works, including representatives of such academic centers as: the faculty of International Studies and Political Science hosted guests from: Warsaw University, The John Paul II Catholic University of Lublin, Jagiellonian University, Adam Mickiewicz University, University of Wrocław, University of Gdańsk, Nicolaus Copernicus University, University of Warmia and Mazury in Olsztyn, Maria Curie-Skłodowska University, Moscow State University, Moscow State Institute of International Studies, State Academy at the President of Russian Federation, Chernivtsi Juriy Fedkovych National University, Kmelnitsky National University, University of Economics and Administration in Prague.

The conference was entirely devoted to the collapse of the Soviet Union and its deep, wide-ranging and complicated consequences. Its works concentrated on debate about: premises, direct and indirect logic behind the Soviet Union's collapse and its long-lasting consequences. Conference participants discussed: the rise of new political and economical systems in Central and Eastern Europe, contours of new international and security order in the region; ethno-political conflicts hunting several CEE subregions; phenomena of hybrid regimes consolidating in CEE region, as well as relations between the Soviet Union's successor - the Russian Federation with its neighbors, including Poland.

There were four main areas of interest at the conference, that corresponds with panel sessions' subject matter: international relations development in the aftermath of the Soviet Union's collapse and the end of the Cold War; establishment of new international and security order in the CEE region; triple and quadruple transition in the region; rise of a new form of authoritarianism, socio-economical transition in Central and Eastern European countries; Polish-Russian relations embedded with Kremlin's modernization efforts.

The plenary session of the conference was dominated by future development of the European Union, its financial problems and ways of overcoming them. The opening speech by prof. Konstanty Adam Wojtaszczyk (Warsaw University) analyzed the European Union's modernization 
prospects, prof. Stefan Höjelid (State University in Växjö) gave a speech about the Euro-zone crisis, its roots, consequences and ways of overcoming it.

There were 8 discussion panels on the first day of the conference, during which their participants debated theoretical aspects new international order consolidation after the Soviet Union dissolution, CEE countries' foreign policy evolution; development of CEE countries' political systems, processes of economical cooperation and integration between former Soviet Bloc countries, prospects of Russian modernization; history, current state of play and perspective of Polish - Russian relations; development of nationhood and statehood processes in the region.

On the second day of the conference discussions on the 4 panels concentrated on such subject matters as: countries of CEE security of state; patterns of interparty and electoral competition; integration and disintegration tendencies in the Post-Soviet area; international consequences the dissolution of the Soviet Union and its impact on individual states and regions of the world.

The conference was accompanied by a second edition of the Chair of Political Science's Project Political Science Debates. October's debate were titled The Status and Research Development in Political Science in Eastern and Central Europe (The Case of Russia, Ukraine, Lithuania and Poland) with participation of the political science association presidents from CEE countries and members of IPSA and were focused on the analysis of the current status of discipline: Political Science in the four East-Central European countries: Russia, Ukraine, Lithuania and Poland. The three topics were discussed : 1) how the democratic experience in the last twenty years influenced the status and research analysis on Political Science in Russia, Ukraine, Lithuania and Poland? 2) Hopes and fears for the democratic development in the above mentioned countries, 3) The current relationship between media and politics. How the public debate on politics generated by the media has influenced the decision making process in these four countries in recent years?

The debate was moderated by prof. Teresa Sasinska-Klas a member of the Executive Committee of IPSA, Jagiellonian University, with the participation of prof. Mikhail Ilyin a member of the Executive Committee of 
IPSA, from the Centre for Advanced Studies in Humanities, the Russian Academy of Sciences, prof. Roman Backer, President of the Polish Association of Political Science, Nicolaus Copernicus University, and Anatolij Kruglashov the Ukrainian Association of Political Science, Institute of Political Science and Sociology, Yuriy Fedkovych Chernivtsi National Univesity. 